\title{
Application of Multivariate Statistical Analysis to Superficial Soils Around a Coal Burning Power Plant
}

\author{
Maria Luiza D. P. Godoy ${ }^{*, a, b}$, José M. Godoy ${ }^{a, b}$, Luis A. Roldão ${ }^{a}$ and Luis F. Conti ${ }^{a}$ \\ ${ }^{a}$ Instituto de Radioproteção e Dosimetria, Comissão Nacional de Energia Nuclear, CP 37750, Barra da Tijuca, \\ 22642-970 Rio de Janeiro, RJ, Brazil \\ ${ }^{b}$ Departamento de Química, Pontifícia Universidade Católica do Rio de Janeiro, Rua Marquês de São Vicente 225, \\ Gávea, 22453-900 Rio de Janeiro, RJ, Brazil
}

\begin{abstract}
O Complexo Termelétrico Jorge Lacerda (CTJL), localizado no Estado de Santa Catarina, Brasil, é o maior complexo termelétrico a carvão da América Latina e consiste de sete unidades com uma capacidade total de $832 \mathrm{MWe}$. De modo a estimar a contribuição das emissões atmosféricas oriundas do CTJL, para a composição elementar de solos superficiais em sua circunvizinhança, quarenta e cinco amostras foram coletadas até uma distância de $8 \mathrm{~km}$. Quarenta e dois elementos foram determinados por ICP-MS e ICP-AES após digestão ácida total. A técnica de análise de componentes principais foi empregada na identificação das fontes de maior significado para a composição do solo superficial. Adicionalmente, foi empregada a técnica de componentes principais absolutos visando a quantificação da contribuição das fontes identificadas na composição química do solo. Baseados nos resultados obtidos, quatro fontes foram identificadas como as principais para a composição elementar do solo superficial. Uma delas foi relacionada com o CTJL, pois continha os elementos voláteis enriquecidos nas cinzas volantes emitidas através das chaminés co compexo.
\end{abstract}

The Thermoelectric Complex Jorge Lacerda (TCJL), located in the Santa Catarina State, Brazil, is the largest coal burning thermoelectric complex of Latin America and consists of seven power plants with a total capacity of $832 \mathrm{MWe}$. In order to estimate the contribution of the atmospheric releases from the TCJL to the elemental composition of surface soils around it, forty-five samples were collected at up to a distance of $8 \mathrm{~km}$. Forty-two elements were determined by ICP-MS and ICPAES after total acid dissolution. The technique of principal component analysis was employed to identify the major sources that contribute to surface soil composition. Additionally, a source apportioning using multiple regression on absolute principal component scores was performed in order to obtain quantitative information about the contribution of the different identified sources on the soil composition. Based on the results obtained, four sources were identified as the main contributors to the surface soil elemental composition. One of them was related to TCJL because it retains volatile elements enriched on fly ash and released from powerhouse stacks.

Keywords: surface soils, ICP-MS, coal fired power plant, elemental composition, chemometrics

\section{Introduction}

Electric power generation in Brazil has been predominantly hydroelectric. Approximately $14 \%$ is of thermoelectric origin, of which a small fraction $(18 \%)$ is from coal burning power plants. There is a clear tendency to increase thermal electric generation by the use of natural gas power plants, but the coal power plants capacity has remained constant due to the quality and geographical

\footnotetext{
* e-mail: malu@ird.gov.b
}

distribution of coal resources. However, large investments are planned for this decade involving both natural gas and coal fired power plants. ${ }^{1}$

The Thermoelectric Complex Jorge Lacerda (TCJL) is located in the township of Capivari de Baixo, in the Southeast area of the state of Santa Catarina, $130 \mathrm{~km}$ from Florianópolis. The TCJL is the largest coal burning thermoelectric complex of Latin America, formed by seven power plants and with a total capacity of $832 \mathrm{MWe}$ (Table 1). ${ }^{2}$ Flat lands of recent sedimentary formation with average altitude of 9 meters above sea level dominate the area around the complex, occupied by rice plantations. The 
complex is located between two cities, Capivari de Baixo and Tubarão. The principal rivers of the area are the Tubarão and Capivari. An aerial view from the TCJL and its environment is shown in Figure 1. The average wind speed is $2 \mathrm{~m} \mathrm{~s}^{-1}$ and its direction distribution is quite homogeneous, futhermore, with a calm frequency of $11.5 \%$ (Figure 2). The meteorological conditions at Jorge Lacerda with weak wind and high frequency of unstable conditions tend to cause air pollition. ${ }^{2}$

Table 1. Thermoelectric Complex Jorge Lacerda, data from JICA ${ }^{2}$

\begin{tabular}{lccc}
\hline Plant & $\begin{array}{c}\text { Capacity } \\
(\mathrm{MWe})\end{array}$ & $\begin{array}{c}\text { Coal consumption } \\
\left(10^{3} \mathrm{t}^{-1}\right)\end{array}$ & $\begin{array}{c}\text { Start up } \\
\text { Date }\end{array}$ \\
\hline J. Lacerda Ia and Ib & 50 & 420 & $\begin{array}{c}\text { Mar-65 } \\
\text { Jan-67 }\end{array}$ \\
& 50 & & Mar-73 \\
J. Lacerda IIa and IIb & 66 & 576 & Feb-74 \\
& 66 & & Feb-80 \\
J. Lacerda IIIa and IIIb & 125 & 840 & Apr-80 \\
& 125 & & Jan-97 \\
J.Lacerda IV & 350 & 1100 & \\
\hline
\end{tabular}

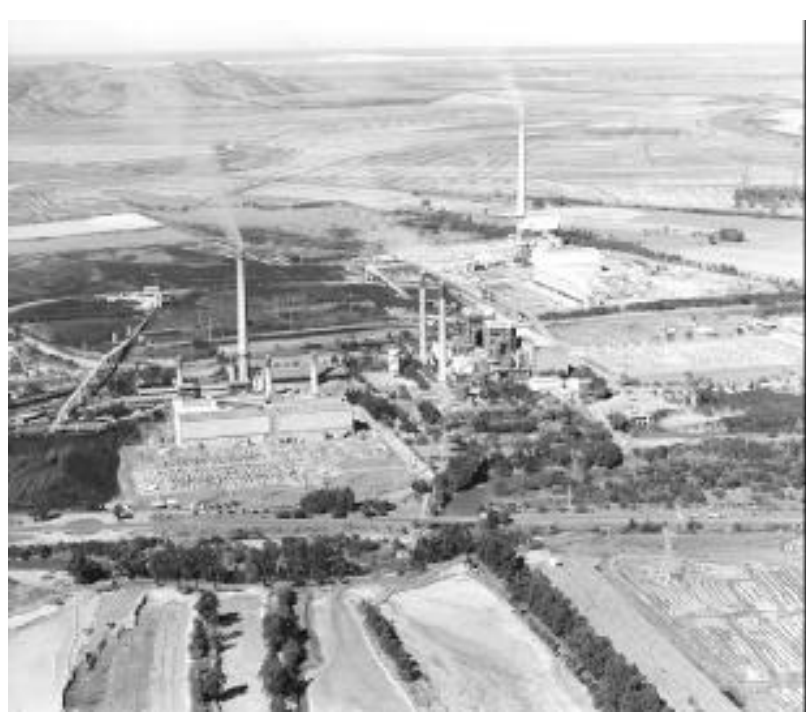

Figure 1. Aerial photograph of the Thermoelectric Complex Jorge Lacerda (TCJL) and its surroundings.

All the units of TCJL have electrostatic precipitators with an efficiency of approximately $98 \%$, which remove particulates in suspension in the gaseous effluent. To help the aerial pollutant dispersions, the 4 older generating units are equipped with a $150 \mathrm{~m}$ chimney. Each $125 \mathrm{MW}$ unit has a $100 \mathrm{~m}$ chimney, and the newest unit of $350 \mathrm{MW}$ has a $200 \mathrm{~m}$ chimney. The power plant operator has an environmental monitoring program related to major pollutants involving $\mathrm{SO}_{2}$ and $\mathrm{NO}_{x}$ automatic monitoring stations and total suspended particulate (TSP) sampling. No environmental data concerning trace elements is available. ${ }^{2}$ Finkelmann and Gross ${ }^{3}$ have proposed twenty-

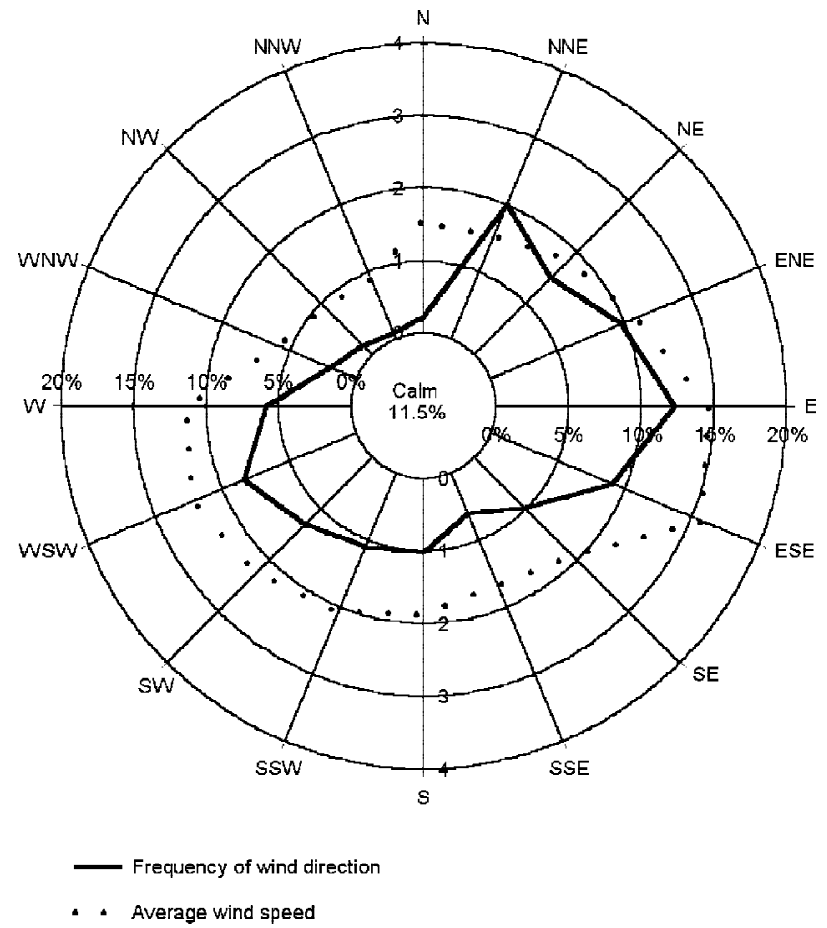

Figure 2. Wind rose diagram at TCJL, data from JICA. ${ }^{2}$

five elements as health hazard; from them nineteen were investigated during the present study.

The objective of this work was to verify the deposition of elements on surface soils due to the TCJL operation and to obtain the local soil signature for further studies concerning particulate material in suspension in the air. To attain these objectives, the use of the absolute principal component analysis (APCA) was investigated. The APCA is usually applied for source apportionment studies related to atmospheric pollution. ${ }^{4-13}$ However, its application on surface soils is not usual. It should allow the estimation of the contribution of each identified source (by principal component analysis) to the soil concentration (mass) of each element. The main advantage of this modeling method is its receptor orientation and the opportunity to evaluate the source emissions without direct measurements.

\section{Experimental}

A radial sampling net as recommended by the Environmental Monitoring Laboratory Manual, EMLUSDOE (1992),${ }^{14}$ was initially planned but was not achieved due to obstacles such as rice plantations, coal and ash deposits and swamps. Forty-five samples of surface soil ( 0 $5 \mathrm{~cm}$ ) were collected around the installation, covering a distance up to $8 \mathrm{~km}$ from the Thermoelectric Complex (Figure 3). The chosen sites were flat, not swampy, noncultivated areas and, when possible, far away from any roads. 


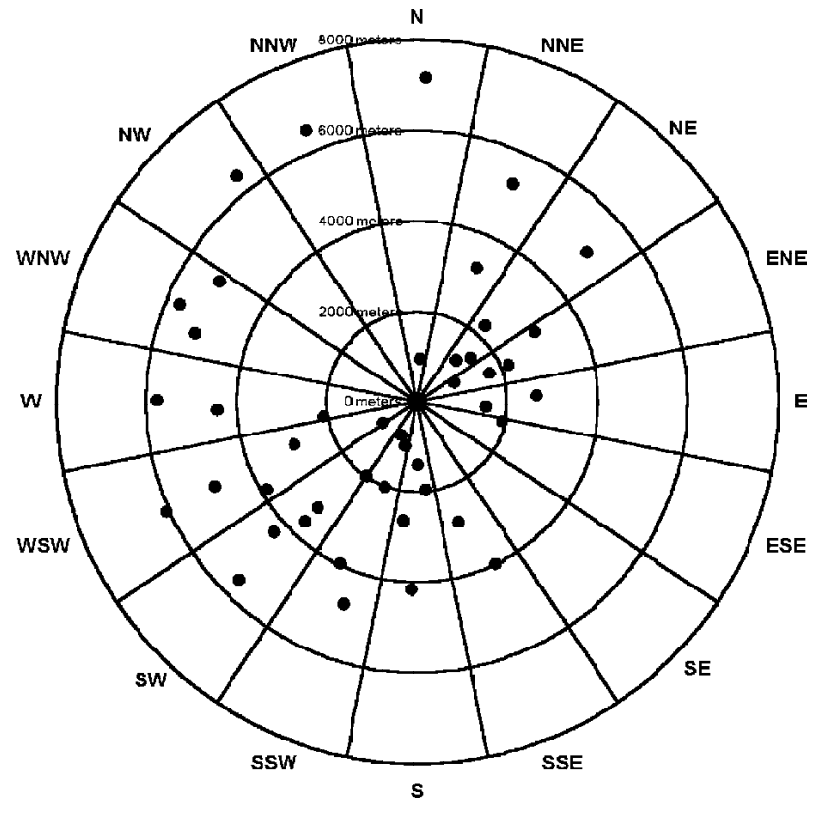

Figure 3. Soil sampling points with the TCJL at the center.
Each sample was a composite of 7 cores, collected in a straight line $50 \mathrm{~cm}$ from each other, taken with a PVC corer of $6.5 \mathrm{~cm}$ diameter and $5 \mathrm{~cm}$ height. ${ }^{14}$ The samples were air-dried, sieved to the $2 \mathrm{~mm}$ fraction and then homogenized by fine grinding with a mortar.

For the determination of elemental contents, each soil sample was analyzed in triplicate. Aliquots of $300 \mathrm{mg}$ were completely dissolved, in closed Teflon ${ }^{\circledR}$ vessels, with a mixture 1:1:1 (v/v/v) of $\mathrm{HNO}_{3}$, $\mathrm{HF}$ and $\mathrm{HClO}_{4} \cdot{ }^{15,16}$ Each acid dissolution batch was composed of 17 Teflon ${ }^{\circledR}$ vessels (15 soil aliquots, a reagent blank and an aliquot of the standard reference material IAEA-356 lake sediment). Major elements ( $\mathrm{Na}, \mathrm{Mg}, \mathrm{Al}, \mathrm{K}, \mathrm{Ca} \mathrm{Ti}$ and $\mathrm{Fe}$ ) were determined by ICP-AES ${ }^{16}$ and trace elements by ICP-MS. ${ }^{15}$

During this work, four interlaboratorial exercises were performed under the USDOE-Mixed Analyte Performance Evaluation Program (MAPEP), two for soil samples and two for water samples (Tables 2 and 3, respectively). For water samples all of them were considered to be acceptable

Table 2. Results obtained during participation in the USDOE Mixed Analyte Performance Exercise Program for soil samples

\begin{tabular}{|c|c|c|c|c|c|c|}
\hline \multirow[t]{2}{*}{ Element } & \multicolumn{2}{|c|}{ Sample MAPEP-99-S6 } & \multirow[t]{2}{*}{$\operatorname{Bias}(\%)$} & \multicolumn{2}{|c|}{ Sample MAPEP-00-S7 } & \multirow[t]{2}{*}{$\operatorname{Bias}(\%)$} \\
\hline & Ref. value $\left(\mathrm{mg} \mathrm{kg}^{-1}\right)$ & Found value $\left(\mathrm{mg} \mathrm{kg}^{-1}\right)$ & & Ref. value $\left(\mathrm{mg} \mathrm{kg}^{-1}\right)$ & Found value $\left(\mathrm{mg} \mathrm{kg}^{-1}\right)$ & \\
\hline As & 26.7 & $27.2 \pm 3.4$ & 2.0 & & & \\
\hline $\mathrm{Ba}$ & & & & 922.7 & $1082 \pm 99$ & 17 \\
\hline $\mathrm{Be}$ & & & & 95 & $91.7 \pm 5.0$ & -3.5 \\
\hline $\mathrm{Cd}$ & 14.41 & $13.8 \pm 1.7$ & -4.5 & 14.3 & $13.33 \pm 0.41$ & -6.8 \\
\hline $\mathrm{Cr}$ & 130.39 & $111 \pm 14$ & -15 & 79 & $73.7 \pm 4.7$ & -6.7 \\
\hline $\mathrm{Ni}$ & 49.59 & $48.7 \pm 6.5$ & -1.8 & 79.7 & $53.2 \pm 1.8$ & -33 \\
\hline $\mathrm{Pb}$ & 77.83 & $80 \pm 10$ & 2.4 & 67 & $68.8 \pm 6.4$ & 2.7 \\
\hline $\mathrm{Se}$ & 9.61 & $12.3 \pm 1.8$ & 28 & 9.51 & $12.3 \pm 1.1$ & 29 \\
\hline $\mathrm{Tl}$ & 96.06 & $91 \pm 11$ & -4.9 & & & \\
\hline $\mathrm{U}$ & & & & 7.53 & $6.46 \pm 0.55$ & -14 \\
\hline $\mathrm{V}$ & 222.33 & $238 \pm 30$ & 7.0 & 176.2 & $195.9 \pm 6.7$ & 11 \\
\hline $\mathrm{Zn}$ & & & & 91.2 & $91.7 \pm 2.1$ & 0.5 \\
\hline
\end{tabular}

\pm signs $=95 \%$ confidence ranges

Table 3. Results obtained during participation in the USDOE Mixed Analyte Performance Exercise Program for water samples

\begin{tabular}{|c|c|c|c|c|c|c|}
\hline \multirow[t]{2}{*}{ Element } & \multicolumn{2}{|c|}{ Sample MAPEP-99-W7 } & \multirow[t]{2}{*}{$\operatorname{Bias}(\%)$} & \multicolumn{2}{|c|}{ Sample MAPEP-00-W8 } & \multirow[t]{2}{*}{$\operatorname{Bias}(\%)$} \\
\hline & Ref. value $\left(\mathrm{mg} \mathrm{kg}^{-1}\right)$ & Found value $\left(\mathrm{mg} \mathrm{kg}^{-1}\right)$ & & Ref. value $\left(\mathrm{mg} \mathrm{kg}^{-1}\right)$ & Found value $\left(\mathrm{mg} \mathrm{kg}^{-1}\right)$ & \\
\hline As & 0.203 & $0.195 \pm 0.002$ & -3.9 & 0.095 & $0.098 \pm 0.002$ & 3.2 \\
\hline $\mathrm{Ba}$ & 50.8 & $48.79 \pm 0.49$ & -4.0 & & & \\
\hline $\mathrm{Be}$ & 0.508 & $0.460 \pm 0.007$ & -9.4 & 0.286 & $0.299 \pm 0.012$ & 4.5 \\
\hline $\mathrm{Cd}$ & 0.305 & $0.292 \pm 0.005$ & -4.3 & 0.381 & $0.392 \pm 0.005$ & 2.9 \\
\hline $\mathrm{Cr}$ & & & & 0.571 & $0.586 \pm 0.025$ & 2.6 \\
\hline $\mathrm{Cu}$ & & & & 1.238 & $1.253 \pm 0.025$ & 1.2 \\
\hline $\mathrm{Ni}$ & & & & 0.571 & $0.591 \pm 0.005$ & 3.5 \\
\hline $\mathrm{Pb}$ & & & & 1.048 & $1.059 \pm 0.010$ & 1.0 \\
\hline $\mathrm{Se}$ & 0.203 & $0.192 \pm 0.005$ & -5.4 & 0.143 & $0.143 \pm 0.007$ & 0.0 \\
\hline $\mathrm{Sb}$ & & & & 0.476 & $0.468 \pm 0.010$ & -1.7 \\
\hline $\mathrm{Tl}$ & 0.508 & $0.489 \pm 0.007$ & -3.7 & & & \\
\hline $\mathrm{U}$ & 0.036 & $0.034 \pm 0.002$ & -5.6 & 0.0826 & $0.079 \pm 0.002$ & -4.4 \\
\hline $\mathrm{V}$ & 0.711 & $0.683 \pm 0.015$ & -3.9 & 5.714 & $5.77 \pm 0.17$ & 0.9 \\
\hline $\mathrm{Zn}$ & 5.08 & $4.55 \pm 0.15$ & -10 & 1.143 & $1.058 \pm 0.020$ & -7.4 \\
\hline
\end{tabular}

\pm signs $=95 \%$ confidence ranges. 
$( \pm 20 \%)$. For soil samples, both results for selenium were classified as acceptable with warning and one for nickel as not acceptable. All the data related to this nickel determination were verified and no reason was found for this result, in particular, because all the other nickel determinations were considered to be acceptable.

The results of the analysis of the standard reference material IAEA-356 were used to build a control chart (Figure 4), which gave information about the achieved accuracy and precision. The control bars $( \pm 20 \%$, acceptable, and $\pm 30 \%$, acceptable with warning) reflect the MAPEP acceptance criteria. Based on this criteria, $\mathrm{Sb}$ and As could be regarded as acceptable with warning and all the others acceptable. Poor arsenic results seem to be related to an analytical problem associated with this sample, since, good results were obtained under the MAPEP program (Tables 2 and 3). For $\mathrm{Sb}$ the observed biases were, in general, negative, probably related to loses during the sample dissolution procedure.

Soil pH, granulometry, cation exchange capacity, sulfur, phosphate and organic matter content, were analyzed by the National Laboratory for Soil Research, belonging to the Brazilian Company for Agricultural Research (EMBRAPA).

In order to identify and evaluate the contribution of the pollutant sources in the soil surrounding the TJCL, in particular, volatile elements such as $\mathrm{As}, \mathrm{Pb}, \mathrm{Cd}$ and $\mathrm{Sb}$, receptors models ${ }^{17}$ were used. A multivariate statistical approach using Principal Component Analysis (PCA), ${ }^{18,19}$ Absolute Principal Component Analysis (APCA) ${ }^{4-13}$ and Hierarchical Cluster Analysis ${ }^{18,19}$ was applied. All the statistical analyses were performed using the Statistical Program for Social Science (SPSS) ${ }^{\circledR}$ version 9.0.

\section{Results and Discussion}

The main soil sample characteristics are showed in Table 4 and their chemical composition is presented in Table 5. The soils are, in general, loam and have an acid $\mathrm{pH}$. Some high phosphate values were observed reflecting

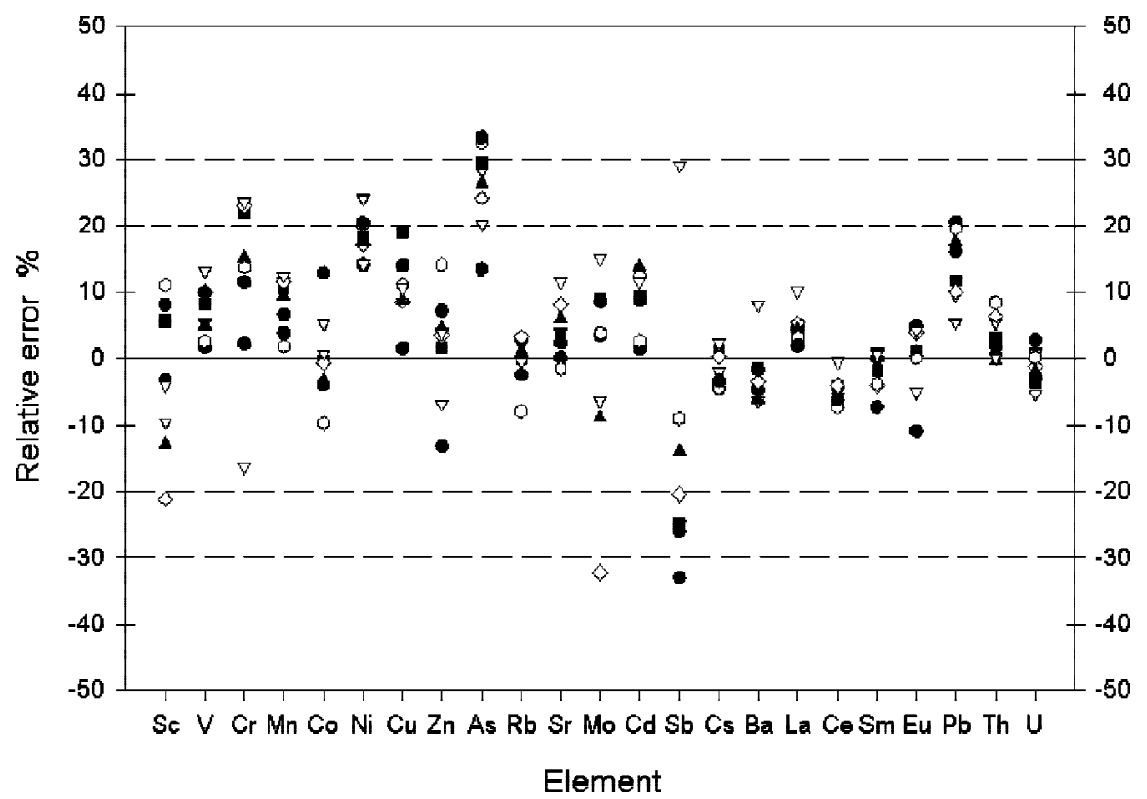

Figure 4. Control chart based on the standard reference material IAEA-356.

Table 4. Descriptive statistics of the main soil characteristics

\begin{tabular}{lccccc}
\hline Characteristic & Cases & Mean & Minimum & Maximum & Standard deviation \\
\hline Coarse sand (\%) & 43 & 24.6 & 0.1 & 72.0 & 21.1 \\
Fine sand (\%) & 43 & 15.1 & 0.1 & 49.6 & 11.8 \\
Silt $(\%)$ & 43 & 39.0 & 8.6 & 69.8 & 17.2 \\
Clay $(\%)$ & 43 & 21.3 & 6.0 & 42.0 & 8.0 \\
$\mathrm{pH}\left(\mathrm{H}_{2} \mathrm{O}\right)$ & 44 & 5.6 & 4.1 & 62.6 & 0.79 \\
$\mathrm{CEC} \mathrm{(meq/100g)}$ & 44 & 23.5 & 5.5 & 159 & 12.5 \\
OC $\left(\mathrm{mg} \mathrm{g}^{-1}\right)$ & 44 & 33.3 & 4.5 & 250 & 35.1 \\
Sulfate $\left(\mu \mathrm{g} \mathrm{g}^{-1}\right)$ & 44 & 26.3 & 7.0 & 2500 & 678 \\
Phosphorus $\left(\mathrm{mg} \mathrm{g}^{-1}\right)$ & 44 & 281 & & & \\
\hline
\end{tabular}


Table 5. Descriptive statistics of the studied elements in superficial soils around the TCJL (values in $\mathrm{mg} \mathrm{kg}^{-1}$ )

\begin{tabular}{|c|c|c|c|c|c|}
\hline Element & Cases & Mean & Minimum & Maximum & $\begin{array}{l}\text { Standard } \\
\text { deviation }\end{array}$ \\
\hline $\mathrm{Li}$ & 44 & 20.8 & 7.32 & 36.7 & 8.2 \\
\hline $\mathrm{Sc}$ & 44 & 6.4 & 0.20 & 16.1 & 3.9 \\
\hline V & 44 & 70.6 & 17.0 & 154 & 36.2 \\
\hline $\mathrm{Cr}$ & 44 & 21.6 & 2.10 & 44.4 & 11.3 \\
\hline Mn & 44 & 407 & 77.0 & 1048 & 249 \\
\hline $\mathrm{Co}$ & 44 & 8.1 & 1.16 & 22.8 & 5.5 \\
\hline $\mathrm{Ni}$ & 44 & 11 & 1.24 & 27.6 & 7.5 \\
\hline $\mathrm{Cu}$ & 44 & 24.1 & 2.63 & 53.8 & 14.9 \\
\hline $\mathrm{Zn}$ & 44 & 86.1 & 22.5 & 190 & 40.6 \\
\hline $\mathrm{Ga}$ & 44 & 15.6 & 4.11 & 29.1 & 5.5 \\
\hline $\mathrm{Ge}$ & 44 & 1.66 & 1.04 & 3.22 & 0.37 \\
\hline As & 44 & 3.6 & 1.63 & 7.02 & 1.3 \\
\hline $\mathrm{Se}$ & 34 & 2.4 & 0.53 & 6.26 & 1.2 \\
\hline $\mathrm{Rb}$ & 44 & 118 & 21.2 & 320 & 63 \\
\hline $\mathrm{Sr}$ & 44 & 64 & 9.29 & 150 & 44 \\
\hline $\mathrm{Y}$ & 44 & 14.5 & 1.65 & 29.5 & 7.4 \\
\hline $\mathrm{Nb}$ & 44 & 18.4 & 4.57 & 34.4 & 6.1 \\
\hline $\mathrm{Ag}$ & 44 & 0.40 & 0.10 & 1.10 & 0.14 \\
\hline $\mathrm{Cd}$ & 44 & 0.14 & 0.02 & 0.47 & 0.10 \\
\hline $\mathrm{Sb}$ & 44 & 0.35 & 0.13 & 1.37 & 0.23 \\
\hline Cs & 44 & 5.0 & 1.25 & 12.2 & 1.8 \\
\hline $\mathrm{Ba}$ & 44 & 291 & 42.1 & 556 & 135 \\
\hline $\mathrm{La}$ & 44 & 19.1 & 0.34 & 53.5 & 11.8 \\
\hline $\mathrm{Ce}$ & 44 & 45 & 3.93 & 149 & 30 \\
\hline $\operatorname{Pr}$ & 44 & 4.9 & 0.06 & 13.5 & 3.0 \\
\hline $\mathrm{Nd}$ & 44 & 18 & 0.38 & 49.9 & 11 \\
\hline $\mathrm{Sm}$ & 44 & 3.7 & 0.07 & 8.91 & 2.2 \\
\hline $\mathrm{Eu}$ & 43 & 0.70 & 0.04 & 1.79 & 0.45 \\
\hline $\mathrm{Gd}$ & 44 & 4.0 & 0.08 & 8.39 & 2.3 \\
\hline $\mathrm{Tb}$ & 43 & 0.57 & 0.03 & 1.17 & 0.30 \\
\hline Dy & 44 & 3.3 & 0.27 & 6.21 & 1.7 \\
\hline Ho & 44 & 0.64 & 0.05 & 1.15 & 0.31 \\
\hline $\mathrm{Er}$ & 44 & 1.91 & 0.21 & 3.44 & 0.87 \\
\hline $\mathrm{Tm}$ & 44 & 0.29 & 0.02 & 0.51 & 0.13 \\
\hline $\mathrm{Yb}$ & 44 & 2.00 & 0.25 & 3.45 & 0.84 \\
\hline $\mathrm{Lu}$ & 44 & 0.29 & 0.02 & 0.53 & 0.12 \\
\hline $\mathrm{W}$ & 44 & 1.42 & 0.33 & 3.50 & 0.57 \\
\hline $\mathrm{Pb}$ & 44 & 30 & 6.12 & 76.8 & 15 \\
\hline $\mathrm{Bi}$ & 44 & 0.32 & 0.06 & 2.08 & 0.31 \\
\hline $\mathrm{Th}$ & 44 & 13.1 & 0.85 & 50.5 & 8.4 \\
\hline $\mathrm{U}$ & 44 & 4.4 & 0.97 & 12.1 & 2.0 \\
\hline $\mathrm{Na}$ & 44 & $3.9 \mathrm{E}+03$ & $3.3 \mathrm{E}+02$ & $7.5 \mathrm{E}+03$ & $2.2 \mathrm{E}+03$ \\
\hline $\mathrm{Mg}$ & 44 & $3.0 \mathrm{E}+03$ & $9.4 \mathrm{E}+01$ & $7.8 \mathrm{E}+03$ & $2.3 \mathrm{E}+03$ \\
\hline $\mathrm{Al}$ & 44 & $2.3 \mathrm{E}+04$ & $2.5 \mathrm{E}+03$ & $6.6 \mathrm{E}+04$ & $1.3 \mathrm{E}+04$ \\
\hline $\mathrm{K}$ & 44 & $2.1 \mathrm{E}+04$ & $4.4 \mathrm{E}+03$ & $4.9 \mathrm{E}+04$ & $9.7 \mathrm{E}+03$ \\
\hline $\mathrm{Ca}$ & 44 & $4.2 \mathrm{E}+03$ & $3.2 \mathrm{E}+02$ & $2.1 \mathrm{E}+04$ & $3.6 \mathrm{E}+03$ \\
\hline $\mathrm{Ti}$ & 44 & $4.8 \mathrm{E}+03$ & $1.6 \mathrm{E}+03$ & $8.9 \mathrm{E}+03$ & $1.8 \mathrm{E}+03$ \\
\hline $\mathrm{Fe}$ & 44 & $2.2 \mathrm{E}+04$ & $5.0 \mathrm{E}+03$ & $4.8 \mathrm{E}+04$ & $1.1 \mathrm{E}+04$ \\
\hline
\end{tabular}

the agriculture activity of this region. The soil sample with the highest phosphate content (sampling point 4 , circa 1 $\mathrm{km}$ from the TCJL on the ENE sector) was eliminated after the statistical tests performed as described below. No statistically valid correlation (95\% significance level) was observed between any soil parameter described in Table 4 and the elements found in Table 5. Therefore, these main soil parameters were excluded from further statistical tests.

Histograms, normal and lognormal distributions were generated to validate the data and remove outliers. For each element, a stepwise linear regression was performed on the validated data set. Those elements that could not be predicted by any other element were excluded from the dataset. In general, these had many results bellow or close to the quantification limit such as $\mathrm{Se}, \mathrm{Ge}, \mathrm{Ag}$ and $\mathrm{Bi}$.

One sampling point (point 4) presented several outlier values such as the elemental concentrations of $\mathrm{Ca}$ and $\mathrm{Zn}$. Its visual examination has shown the presence of shale fragments, and, therefore, it was excluded from the dataset. The validated data set had 44 sampling points and 44 variables.

According to Henry et al. ${ }^{20}$ in order to obtain reliable results of a multivariate model in ecological applications, the degrees of freedom per variable should be at least 30 , as a consequence, for 44 samples no more than 24 variables should be used for the Principal Component Analysis. In order to reduce the number of variables involved, additional criteria were applied: Preliminary PCA tests have shown that the lanthanides built a separate group; therefore it was decided to exclude them from the PCA evaluation. Due to the fact that $\mathrm{Fe}$ and $\mathrm{Mn}$ and $\mathrm{Mg}$ and $\mathrm{Ca}$ show a strong correlation, only one of each pair was included (Fe and $\mathrm{Mg}$ ). Other elements such as $\mathrm{Li}, \mathrm{Rb}, \mathrm{Cs}, \mathrm{Ba}, \mathrm{Nb}$ and $\mathrm{W}$ were also excluded in order to preserve others such as $\mathrm{Zn}$, $\mathrm{Sb}$ or As, which are enriched in fly ashes ${ }^{15}$ and, therefore, more relevant for the present study. After these exclusions, there was a reduction for 21 variables and 44 samples. In Table 6, PCA results are presented with the elements retained in each component and their communalities. The communality represents how good the presence of one particular element is explained by the components selected. Based on the criteria defined by Hopke, ${ }^{17}$ when an element has shown a factor loading greater than 0.4 it was considered to belong to this component. A soil component means a soil phase or a mineral present with at least one of the selected elements associated with it. The four components chosen are able to explain $85.3 \%$ of data set variability.

Components 1 and 2 seem to represent the soil matrix. The first component is related to the oxides of iron (manganese) and titanium present in soils. To this phase are also associated metals such as nickel, chromium and copper. The second component with aluminum and also with the presence of potassium, iron and scandium associates it to clay minerals. The radioactive elements uranium and thorium are also associated with this soil phase. The third component was attributed to TCLJ and includes the elements strongly concentrated in the fly ashes as $\mathrm{As}, \mathrm{Zn}, \mathrm{Cd}, \mathrm{Pb}$ and $\mathrm{Sb}$. However, $\mathrm{As}, \mathrm{Cd}, \mathrm{Pb}$ and $\mathrm{Zn}$ have expressive soil contributions, in contrast to $\mathrm{Sb}$ where the main source seems to be the TCJL. The fourth component 
Table 6. Varimax rotated factor loadings matrix and communalities obtained with principal components analysis for the studied elements in the superficial soils around the TCJL (EV-eigenvalue, VARexplained variance and CVAR-cumulative variance explained $)^{\mathrm{a}}$

\begin{tabular}{lccccc}
\hline Element & Comp. 1 & Comp. 2 & Comp. 3 & Comp. 4 & Communality \\
\hline $\mathrm{Co}$ & $\mathbf{0 . 9 5}$ & - & 0.17 & - & 0.94 \\
$\mathrm{~V}$ & $\mathbf{0 . 9 5}$ & - & 0.15 & -0.16 & 0.96 \\
$\mathrm{Ni}$ & $\mathbf{0 . 9 4}$ & - & 0.24 & - & 0.95 \\
$\mathrm{Mg}$ & $\mathbf{0 . 9 4}$ & - & - & - & 0.89 \\
$\mathrm{Cu}$ & $\mathbf{0 . 9 0}$ & - & 0.23 & - & 0.88 \\
$\mathrm{Fe}$ & $\mathbf{0 . 8 9}$ & 0.33 & 0.15 & - & 0.94 \\
$\mathrm{Sr}$ & $\mathbf{0 . 8 8}$ & -0.10 & 0.22 & 0.18 & 0.88 \\
$\mathrm{Cr}$ & $\mathbf{0 . 8 8}$ & - & 0.33 & -0.14 & 0.91 \\
$\mathrm{Sc}$ & $\mathbf{0 . 8 6}$ & 0.35 & 0.21 & -0.10 & 0.91 \\
$\mathrm{Ti}$ & $\mathbf{0 . 8 3}$ & - & - & -0.28 & 0.77 \\
$\mathrm{Na}$ & $\mathbf{0 . 7 4}$ & -0.14 & - & $\mathbf{0 . 4 9}$ & 0.81 \\
$\mathrm{Th}$ & - & $\mathbf{0 . 9 4}$ & 0.11 & - & 0.91 \\
$\mathrm{U}$ & -0.21 & $\mathbf{0 . 8 8}$ & 0.21 & - & 0.86 \\
$\mathrm{Al}$ & 0.18 & $\mathbf{0 . 8 6}$ & - & 0.14 & 0.80 \\
$\mathrm{Ga}$ & 0.33 & $\mathbf{0 . 8 5}$ & 0.19 & 0.12 & 0.88 \\
$\mathrm{Sb}$ & 0.16 & - & $\mathbf{0 . 8 3}$ & -0.18 & 0.76 \\
$\mathrm{Cd}$ & $\mathbf{0 . 4 4}$ & - & $\mathbf{0 . 6 9}$ & 0.13 & 0.69 \\
$\mathrm{~Pb}$ & -0.20 & $\mathbf{0 . 4 0}$ & $\mathbf{0 . 6 6}$ & 0.39 & 0.79 \\
$\mathrm{Zn}$ & $\mathbf{0 . 4 4}$ & 0.18 & $\mathbf{0 . 6 6}$ & 0.28 & 0.74 \\
$\mathrm{As}$ & $\mathbf{0 . 4 5}$ & 0.34 & $\mathbf{0 . 6 2}$ & -0.31 & 0.80 \\
$\mathrm{~K}$ & -0.18 & 0.31 & - & $\mathbf{0 . 8 4}$ & 0.84 \\
$\mathrm{EV}$ & 9.6 & 3.8 & 2.9 & 1.6 & \\
$\mathrm{VAR}(\%)$ & 45.8 & 18.2 & 13.9 & 7.4 & \\
$\mathrm{CVAR}(\%)$ & 45.8 & 63.9 & 77.9 & 85.3 & \\
\hline
\end{tabular}

a Only factor loadings large than 0.1 are shown and in bold those higher than 0.4 .

includes sodium and potassium indicating some marine aerosol and biomass contributions.

In order to validate the PCA results, a hierarchical cluster analysis was performed including the components factor scores retained in the PCA as new variables. The obtained result was in agreement with that described above. Four clusters were observed, each one including the elements belonging to each component obtained in the PCA together with the correspondent component factor scores, as it is shown in Figure 5. The same results were obtained using both PCA and cluster analysis indicating that the database is valid.

In order to obtain the relative contribution from each source type to the measured mean concentration of elements, in particular of those elements defined as hazardous by Finkelmann and Gross, ${ }^{3}$ an absolute principal component analysis was performed..$^{4-13}$ The results obtained (Table 7) show that, together with the TCJL component, the soil matrix (PCA components 1 and 2) contributes a significant percentage of mass content of As, $\mathrm{Pb}$ and $\mathrm{Zn}$ in the surface soils. On the other hand, the TCJL component (component 3 ) represents $2 / 3$ of the soil content of $\mathrm{Sb}$ and $1 / 2$ of the soil content of $\mathrm{Cd}$. The $\mathrm{S} / \mathrm{M}$ values close to one show that the calculated elemental concen-

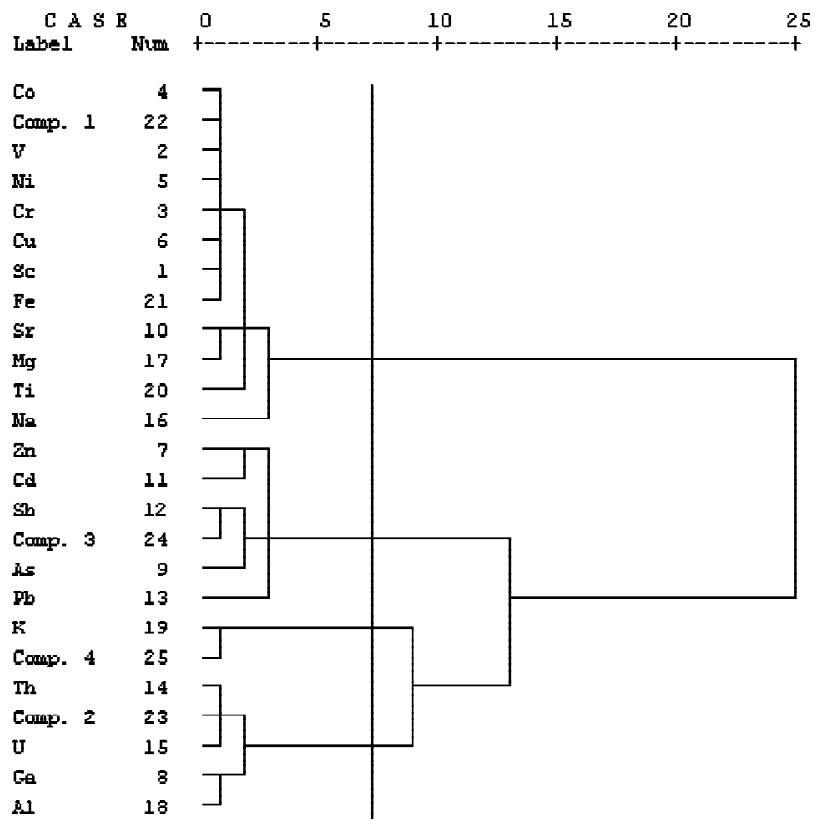

Figure 5. Hierarchical cluster analysis dendrogram showing the distance between the elements, with the PCA factor scores included as new variables.

trations in soil are in agreement with the observed mean values. The pie charts shown in Figure 6 illustrate better these relative contributions.

In spite of this TCJL contribution, the mean value observed for the elements of the component 3 are similar to those reported by other authors ${ }^{21-23}$ as shown in Table 8 .

The distribution with distance from TCJL for some elements belonging to components 1-4 is shown in Figure $7 \mathrm{a}-\mathrm{d}$. As there is not a well-defined main wind direction a symmetric distribution in relation to the complex is expected for those elements with significatant contributions from atmospheric releases from TCJL. A maximum at some distance from the complex is also expected coinciding to the plume touchdown. Due to the presence of coal and ash deposits around the complex, elevated concentrations close to the complex are also expected. The curve (c) with As and $\mathrm{Zn}$ is the one that more closely corresponds to the above description. Thus the Figure 7 (c) with elements belonging to component 3 represents atmospheric releases from the TCJL.

\section{Conclusions}

Based on the application of multivariate data treatment methods, it was possible to identify the origin of metals in surface soils around the Thermoelectric Complex Jorge Lacerda (TCJL). In particular, it was possible to verify that the thermoelectric complex contributes with a significant 
Table 7. Results of source apportionment obtained by the application of APCA, and the ratio between the calculated concentration in soil to the observed mean value (values in $\mathrm{mg} \mathrm{kg}^{-1}$ ) a

\begin{tabular}{|c|c|c|c|c|c|c|c|}
\hline Element & $\begin{array}{l}\text { Comp. } 1 \\
\text { Soil } 1\end{array}$ & $\begin{array}{l}\text { Comp. } 2 \\
\text { Soil } 2\end{array}$ & $\begin{array}{l}\text { Comp. } 3 \\
\text { TCJL }\end{array}$ & $\begin{array}{c}\text { Comp. } 4 \\
\text { Biomass and Sea }\end{array}$ & $\begin{array}{l}\text { Calculated } \\
\text { value }(\mathrm{S})\end{array}$ & $\begin{array}{l}\text { Observed mean } \\
\text { value }(\mathrm{M})\end{array}$ & $\mathrm{S} / \mathrm{M}$ \\
\hline $\mathrm{Sc}$ & 4.40 & 1.88 & 0.70 & - & 6.98 & 6.35 & 1.10 \\
\hline V & 52.75 & 9.64 & 9.24 & - & 71.63 & 70.58 & 1.01 \\
\hline $\mathrm{Cr}$ & 14.98 & 1.90 & 5.09 & - & 21.97 & 21.58 & 1.02 \\
\hline $\mathrm{Co}$ & 7.27 & - & 0.97 & 0.07 & 8.31 & 8.10 & 1.03 \\
\hline $\mathrm{Ni}$ & 9.98 & - & 2.05 & - & 12.02 & 10.96 & 1.10 \\
\hline $\mathrm{Cu}$ & 19.68 & 0.04 & 4.52 & - & 24.24 & 24.11 & 1.01 \\
\hline $\mathrm{Zn}$ & 25.87 & 13.53 & 32.63 & 12.91 & 84.94 & 86.06 & 0.99 \\
\hline $\mathrm{Ga}$ & 3.23 & 9.15 & 1.66 & 1.13 & 15.17 & 15.59 & 0.97 \\
\hline As & 1.16 & 1.27 & 1.24 & - & 3.67 & 3.63 & 1.01 \\
\hline $\mathrm{Sr}$ & 54.05 & - & 10.75 & 8.71 & 73.50 & 63.96 & 1.15 \\
\hline $\mathrm{Cd}$ & 0.06 & - & 0.08 & 0.01 & 0.15 & 0.14 & 1.06 \\
\hline $\mathrm{Sb}$ & 0.07 & 0.06 & 0.25 & - & 0.38 & 0.35 & 1.07 \\
\hline $\mathrm{Pb}$ & - & 12.54 & 12.79 & 7.09 & 32.42 & 30.17 & 1.07 \\
\hline $\mathrm{Th}$ & - & 13.52 & 0.78 & - & 14.30 & 13.14 & 1.09 \\
\hline $\mathrm{U}$ & - & 3.60 & 0.71 & 0.20 & 4.51 & 4.36 & 1.03 \\
\hline $\mathrm{Na}$ & $2.44 \mathrm{E}+03$ & - & 322 & $1.32 \mathrm{E}+03$ & $4.08 \mathrm{E}+03$ & $3.92 \mathrm{E}+03$ & 1.04 \\
\hline $\mathrm{Mg}$ & $2.94 \mathrm{E}+03$ & - & 71 & 114 & $3.12 \mathrm{E}+03$ & $3.00 \mathrm{E}+03$ & 1.04 \\
\hline $\mathrm{Al}$ & $3.06 \mathrm{E}+03$ & $1.92 \mathrm{E}+04$ & - & $1.60 \mathrm{E}+03$ & $2.39 \mathrm{E}+04$ & $2.33 \mathrm{E}+04$ & 1.03 \\
\hline $\mathrm{K}$ & - & $8.73 E+03$ & $1.49 \mathrm{E}+03$ & $1.01 \mathrm{E}+04$ & $2.03 E+04$ & $2.09 \mathrm{E}+04$ & 0.98 \\
\hline $\mathrm{Ti}$ & $2.94 \mathrm{E}+03$ & $1.03 E+03$ & 425 & - & $4.40 \mathrm{E}+03$ & $4.76 \mathrm{E}+03$ & 0.92 \\
\hline $\mathrm{Fe}$ & $1.41 \mathrm{E}+04$ & $6.38 \mathrm{E}+03$ & $1.96 \mathrm{E}+03$ & - & $2.24 \mathrm{E}+04$ & $2.21 \mathrm{E}+04$ & 1.01 \\
\hline
\end{tabular}

${ }^{a}$ Only statistical significant regression coefficients within $95 \%$ confidence interval are shown.
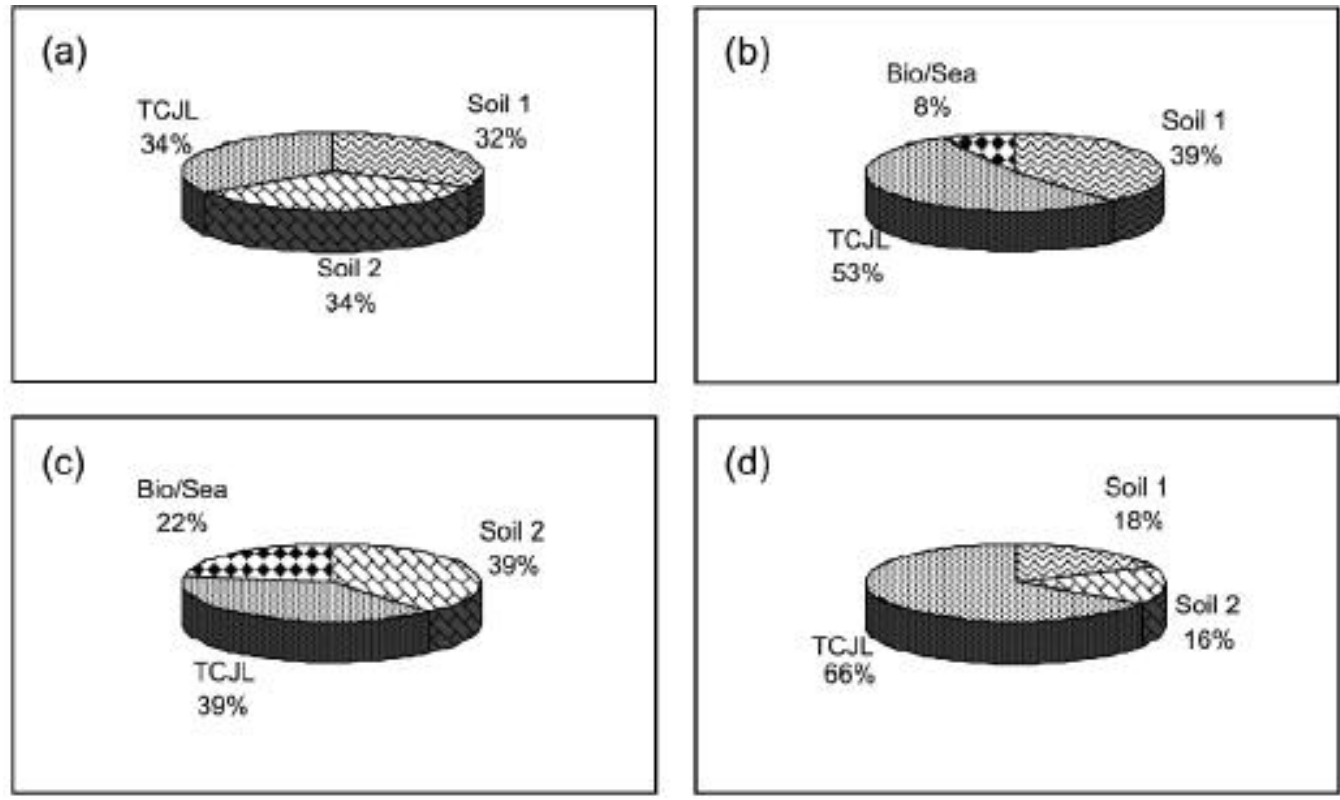

\section{(d)}
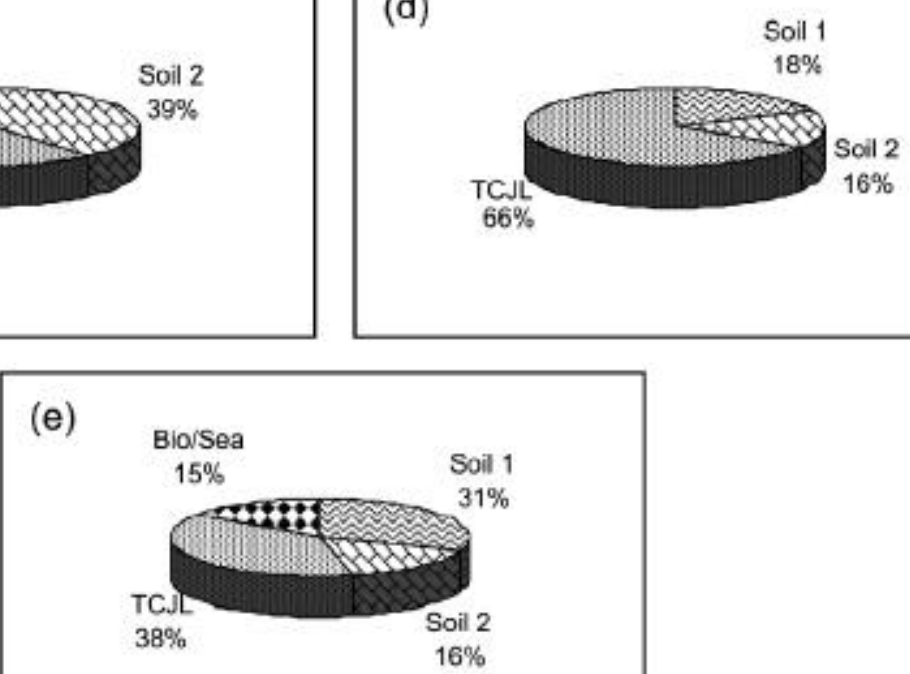

Figure 6. Pie chart of component 3 representative elements: (a) As, (b) $\mathrm{Cd}$, (c) $\mathrm{Pb}$, (d) $\mathrm{Sb}$, (e) $\mathrm{Zn}$. 
Table 8. Comparison of trace element concentrations among the present work and other authors, values in $\mathrm{mg}_{\mathrm{kg}}{ }^{-1}$

\begin{tabular}{|c|c|c|c|c|c|c|}
\hline \multirow[t]{2}{*}{ Element (mean value) } & \multirow[t]{2}{*}{ This work } & \multicolumn{2}{|c|}{ Abollino et al. ${ }^{21}$} & \multicolumn{2}{|c|}{ Chen et al..$^{22}$} & \multirow[t]{2}{*}{ Facchinelli et al..$^{23}$} \\
\hline & & rural & urban & rural & urban & \\
\hline $\mathrm{Cr}$ & 21.6 & $70-100$ & & & & 46.1 \\
\hline Co & 8.10 & & & & & 19.0 \\
\hline $\mathrm{Ni}$ & 11.0 & 50 & & & & 83.1 \\
\hline $\mathrm{Cu}$ & 24.1 & $20-30$ & & 9.14 & 16.1 & 58.3 \\
\hline $\mathrm{Zn}$ & 86.1 & 50 & & 51.0 & 58.8 & 62.7 \\
\hline As & 3.63 & & & 10.7 & 16.5 & \\
\hline $\mathrm{Cd}$ & 0.14 & $0.2-1$ & & 0.74 & 0.94 & \\
\hline $\mathrm{Pb}$ & 30.2 & $10-30$ & $30-100$ & 40.6 & 89.9 & 16.1 \\
\hline
\end{tabular}
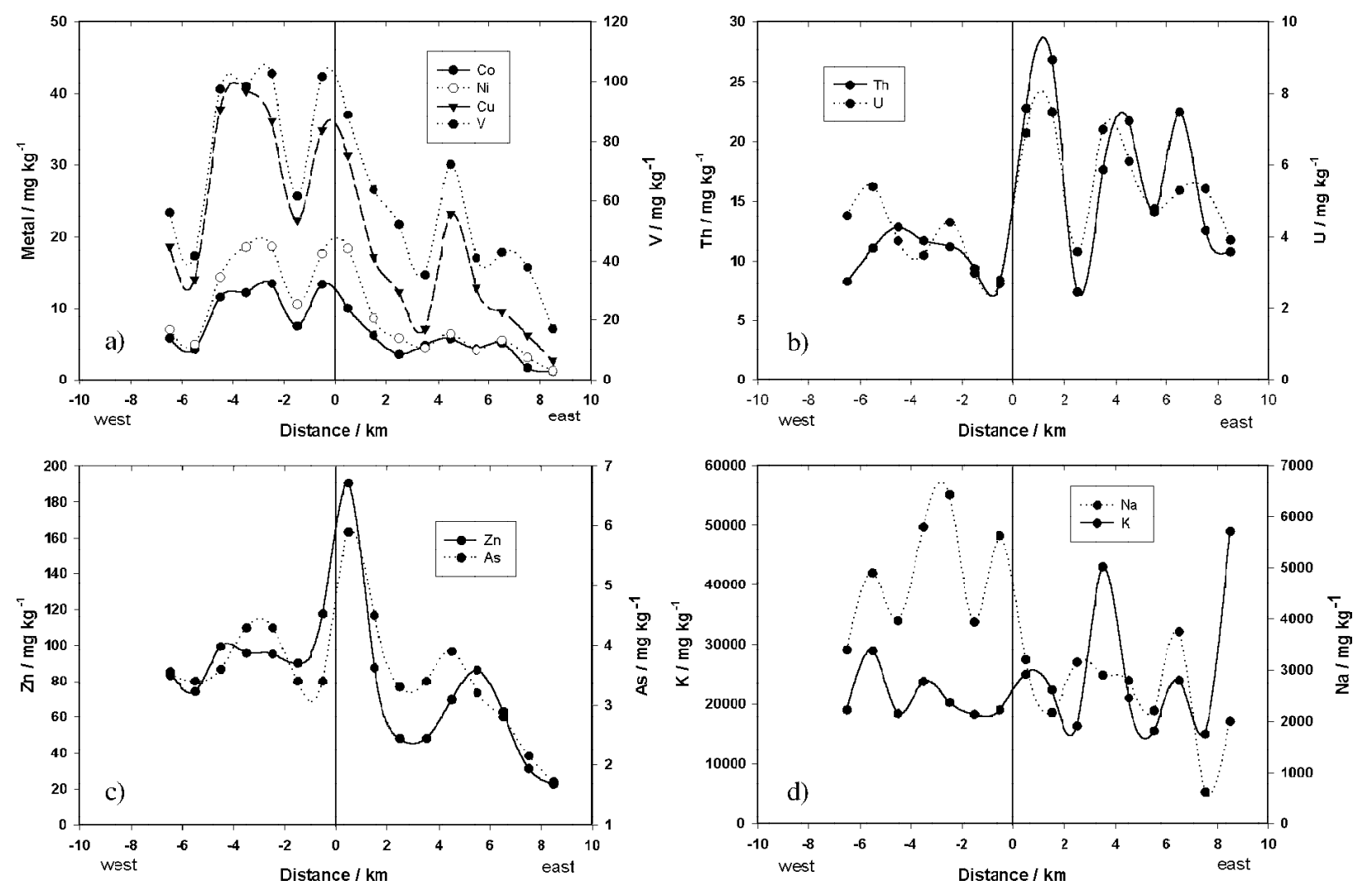

Figure 7. Concentration (in $\mathrm{mg} \mathrm{kg}^{-1}$ ) of elements from component 1 (a), component 2 (b), component 3 (c) and component 4 (d) at different distances (in $\mathrm{km}$ ) from the TCJL.

percentage of element concentrations such as $\mathrm{As}, \mathrm{Cd}, \mathrm{Pb}$, $\mathrm{Sb}$ and $\mathrm{Zn}$ in the surface soils around it. Notwithstanding, when these concentrations are compared with those reported by other authors, one may conclude that, in spite of this input, these cannot be taken as high concentrations.

\section{Acknowledgments}

The present work was partially supported by the Conselho Nacional de Desenvolvimento Científico e Tecnológico (CNPq) under the research contract number 460958/2000-3. The authors would like to express their gratitude to Prof. Paulo Artaxo at the Department of
Physics, University of São Paulo, Brazil, Prof. Ricardo Aucélio at the Department of Chemistry, Pontifícia Universidade Católica do Rio de Janeiro, and Prof. John Hunt, Instituto de Radioproteção e Dosimetria, Comissão Nacional de Energia Nuclear, for their valuable comments on the manuscript. The authors would like to express their gratitude to José Lourival Magri for the aerial photograph of the Thermoelectric Complex Jorge Lacerda (TCJL).

\section{References}

1. http://www.provedor.nuca.ie.ufrj.br/eletrobras/, accessed June 2002. 
2. Japan International Cooperation Agency (JICA); The Study on Evaluation of Environmental Quality in Regions under Influence of Coal Steam Power Plants in the Federal Republic of Brazil, Final Report, Tokyo, Japan, 1997.

3. Finkelman, R. B.; Gross, P. M. K.; Int. J. Coal Geol 1999, 40, 91.

4. Artaxo, P.; Oyola, P.; Martinez, R.; Nucl. Instrum. Methods Phys. Res., Sec. B 1999, 150, 409.

5. Baek, S.; Choi, J.; Hwang, S.; Environ. Int. 1997, 23, 205.

6. Borbély-Kiss, I.; Kottay, E.; Szabó, G.Y.; Bozó, L.; Tar, K.; J. Aerosol Sc. 1999, 30, 369.

7. Gerab, F.; PhD Thesis, Instituto de Física, Universidade de São Paulo, São Paulo, Brazil, 1996.

8. Gidhagen, L.; Kahelin, H; Schmidt-Thomé, P.; Johansson, C.; Atmos. Environ. 2002, 36, 3803.

9. Maenhaut, W.; Fernández-Jiménez, M.T.; Rajta, I.; Artaxo, P; Nucl. Instrum. Methods Phys. Res., Sec. B 2002, 189, 243.

10. Manoli, E.; Voutsa, D.; Samara, C.; Atmos. Environ. 2002, 36, 949.

11. Spanos, Th; Simeonov, V; Andreev, G.; Talanta 2002, 58, 367.

12. Swietlicki, E.; Puri, S.; Hansson, H.; Edner, H.; Atmos. Environ. 1997, 30, 2795.

13. Swietlicki, E.; Krejci, R.; Nucl. Instrum. Methods Phys. Res., Sec. B 1996, 110, 519 .
14. Environmental Measurements Laboratory (EML), United State Department of Energy (USDOE), Procedures Manual; HASL300, New York, 1992, p. 2.1-2.88.

15. Godoy, M. L., Godoy, J. M.; Roldão, L. A.; At. Spectros. 2001, 21, 235

16. . Horton, J. H.; Dorsett, R. S.; Cooper R. E.; Trace Elements in the Terrestrial Environment of a Coal Fired Powerhouse, DP1475/UC-11, 1997.

17. Hopke, P. K. In Elemental Analysis of Airborne Particles; Landsberger, S., Creatchman, M. eds., Gordon and Breach Science Publishers: Amsterdam, 1999, pp. 273-315.

18. Johnson, R.; Wichern, D.; Applied Multivariate Statistical Analysis, Prentice Hall: New Jersey, 1998, p. 816.

19. Legrende, P.; Legrende, L.; Numerical Ecology: Developments in Environmental Modelling, $2^{\text {nd }}$ ed.; Elsevier: New York, 1998, p. 853.

20. Henry, R. C.; Lewis, C. W.; Hopke, P. K.; Williamson, H. J.; Atmos. Environ. 1984, 18, 1507.

21. Abollino, O.; Aceto, M.; Malandrino, M.; Mentasti, E.; Sarzanini, C.; Barberis, R.; Environ. Pollut. 2002, 119, 177.

22. Chen, T.B.; Wong, J.W.C.; Zhou, H.Y.; Wong, M.H.; Environ. Pollut. 1997, 96, 61.

23. Facchinelli, A.; Sacchi, E.; Mallen, L.; Environ. Pollut. 2001 , 114, 313. 